\title{
Comparison of Anaerobic Capacities of Lower and Upper Extremity in Basketball Players
}

\section{Basketbolcularda Alt ve Üst Ekstremiteye Ait Anaerobik Kapasitelerin Karşılaştırılması}

Yusuf Bozdemir

Faculty of Sport Sciences, Karamanoğlu Mehmetbey University

\section{Recep Soslu ${ }^{1}$}

Faculty of Sport Sciences, Karamanoğlu Mehmetbey University

\section{İsmail Can Çuvalcıoğlu}

Faculty of Sport Sciences, Karamanoğlu Mehmetbey University

Received: May 3, 2021

Accepted: September 2, 2021 https://orcid.org/0000-0001-8444-6824

https://orcid.org/00oo-0003-3751-0631

https://orcid.org/0000-0002-2651-3408

Online Published: September 30, 2021

DOI: $10.30655 /$ besad.2021.35

https://doi.org/10.30655/besad.2021.35

\section{Öz}

Bu çalışmanın amacı, basketbolcularda üst ve alt ekstremiteye ait anaerobik gücün sürati hangi düzeyde etkilediğinin belirlenmesidir. Çalışmaya sırasıyla boy, kilo ve yaşları $185.98 \pm 4.26 \mathrm{~cm}, 79.01 \pm 5.48 \mathrm{~kg}$ ve $21.88 \pm 1.05$ yıl) olan toplam 14 erkek basketbolcu dahil edilmiştir. Basketbolcuların alt ve üst anaerobik güçleri, sırt bacak ve el kavrama kuvveti, sürat ve laktat değerleri ölçülmüştür. Elde edilen verilerin analizinde değişkenler arasındaki ilişkiyi belirlemek için Lineer Regresyon Analizi kullanıldı. Elde edilen sonuçlarda basketbolcuların 20m süratile bağımlı değişkenlerüst ekstremite zirve güç, üst ekstremite ortalama güç, üst ekstremite en yüksek güçte zaman, alt ekstremite zirve güç, alt ekstremite ortalama güç, alt ekstremite en yüksek güçte zaman değerleri arasında $(F(6,13)=.55, p>.05, R 2=-.25)$, bacak sırt ve el kavrama kuvvet değerleri arasında Regresyon analizi sonucuna göre istatistiksel olarak anlamlı fark tespit edilmemiştir $(F(6,13)=.22, p>.05, R 2=-.31$. Basketbolcuların ön ve son test laktat değerleri arasında son test değerlerin ön test değerlerine göre istatistiki açıdan farklı olduğu tespit edilmiştir $(p<0,05)$. Sonuç olarak basketbolculardaki anaerobik gücün müsabaka anında önemli bir etken olacağı bunun da sporcuların performanslarını pozitif yönde etkileyeceği düşünülebilir.

Anahtar Kelimeler: Güç, kuvvet, 20 m sprint, kan laktat

\footnotetext{
${ }^{1}$ Corresponding Author: Recep Soslu

recepsosli@gmail.com

Faculty of Sport Sciences, Karamanoğlu Mehmetbey Üniversitesi, Karaman, Türkiye.
} 


\section{Abstract}

The aim of this study is to determine to what extent the anaerobic power of the upper and lower extremities affects the speed in basketball players. A total of 14 male basketball players with height, weight and age $185.98 \pm 4.26 \mathrm{~cm}$, $79.01 \pm 5.48 \mathrm{~kg}$ and $21.88 \pm 1.05$ years), respectively, were included in the study. Upper and lower anaerobic power, back leg and hand grip strength, speed and lactate values of basketball players were measured. In the analysis of the obtained data, Linear Regression Analysis was used to determine the relationship between the variables. In the results obtained, the dependent variables of basketball players with $20 \mathrm{~m}$ sprint were upper extremity peak power, upper extremity average power, upper extremity peak power time, lower extremity peak power, lower extremity average power, lower extremity peak power time values $(F(6,13))=.55,. p>.05, R 2=-.25)$, no statistically significant difference was found between the leg-back and hand grip strength values according to the results of the regression analysis $(F(6.13)=.22$, $p>05, R 2=-31$ ). It was determined that the post-test values between the pre- and post-test lactate values of the basketball players were statistically different from the pre-test values $(p<0.05)$. As a result, it can be thought that the anaerobic power of basketball players will be an important factor during the competition, and this will positively affect the performance of the athletes.

Keywords: Power, strength, 20 m sprint, blood lactate

\section{Giriş}

Basketbol, tekrar edilen yüksek şiddetli egzersizler (ofansif ve defansif geçişler, sprint, sıçrama, blok, ribaunt vb) için temelde \%80 anaerobik enerji sisteminin (\%60 fosfojen ve \%20 laktik asit) kullanıldığı yüksek şiddetli bir takım sporudur (Castagna vd., 2008). Basketbol müsabakası sırasında kreatin fosfat (PCr) sentezini artırmak, aktif durumdaki kaslardan laktat atımını gerçekleştirmek ve hücre içerisinde biriken inorganik fosfatın atımasını sağlamak için yüksek seviyede aerobik metabolizmaya da intiyaç duyulur. Sporcular her biri ortalama 2 sn süren bine yakın şiddet seviyesi yüksek aksiyonları (sıçrama, sprint, blok, ribaunt, ani yön değişikliği, top sürme vb) gerçekleştirir (Abdelkrimye vd., 2007). Şiddet seviyesi yüksek olan bu egzersizler müsabakanın yalnızca \%15' lik bir kısmını oluşturmasına rağmen maçın sonucuna önemli bir etki ederek büyük katkı sağlamaktadır. Sporcular basketbola özgü kısa süreli yüksek şiddetli egzersizleri, kısa süre içerisinde laktik asit ve ATP-PCr ile ortaya çıkan enerji ile gerçekleştirmektedir (Ziv\&Lidor, 2009). Bununla birlikte basketbolda 6 sn ve daha kısa süren yüksek şiddetli egzersizlerden sonra 22 sn' lik düşük şiddetli egzersizler (jogging vb) esnasında toparlanmalarını tamamladıkları belirtilmektedir (Kostromin, 2015). Bu bağlamda basketbolcuların fiziksel uygunluk ve oyun performansı düzeylerinin aerobik ve anaerobik metabolizmanın etkisinde kaldığı söylenebilir (Montgomery vd., 2010). Basketbolcuların başarı seviyesi, yüksek şiddetli antrenmanlar ve yılmadan tekrarlanan çalışmaların neticesinde hızlı, kuvvetli ve dayanıklı bir tekniğe sahip olması ile geliştirilir. Oyun esnasında hızlı ve doğru oyun sergileyebilme becerisi ile hızı hücuma çıkabilmek ve bunu devam ettirebilmek basketbolcuların performansını arttırmaktadır (Menevşe, 2013). Aerobik kapasite seviyesinin yüksek olması kas içi PCr depolarındaki kapasiteye paralel olarak hızlı bir şekilde dolar ve oyun içerisinde aktif olduğu süreye bağlı olarak daha başarılı bir performans çizelgesi ortaya çıkar (Güngör, 2019).

Spor bilimleri ve fizyolojik açıdan kuvvet, istemli bir şekilde kasın ya da kas gruplarının bir dirence karşı bir defa kasılarak üretmiş olduğu en yüksek seviyedeki kasılma gücü ve o direnci yenmek olarak tanımlanır (Özdenk, 2019). Kuvvet kavramı bireyin temelde bulunan bir özelliğidir ve antrenman yüklenmeleri ile farklıık gösterip, gelişim gösteren sportif güç verimliliğinin temel öğesidir (Sevim, 2002). Vücutta bulunan hemen hemen tüm kas gruplarının aktif olarak çalıştığı bir spor branşı olan basketbolda kuvvet, maksimal, patlayıcı (güç), kuvvete devamlılık olarak farklı biçimde ortaya çıkar. Müsabaka sırasında oluşan ikili mücadelelerde, pas ve şut esnasındaki kol kuvveti veya sıçrama esnasındaki bacak kuvveti, pota alındaki mücadele ve hücum ribauntlarındaki gövde kuvveti bu durumun göze çarpan en 
etkin özellikleridir (Atlı, 2009). Bununla birlikte verimliliğin artmasına sebep olan temel motorik özelliklerden biri olan sürat, genel anlamda sporcunun kendisini en yüksek hızda bulunduğu yerden farklı bir yere hareket ettirebilme veya hareketlerin olabildiğince en yüksek hızla uygulama becerisi olarak tanımlanır (Bompa, 2011). Sürat, bireyin genetik olarak kazanmış olduğu, geliştirilmesi kısıtlı olan ancak çalışıldığı takdirde zamanla iyileştirilip geliştirilebilen bir özelliktir (Hamzaoğulları, 200g). Basketbolda da sporcuların, en kısa sürede potaya gidip hareketini sonlandırması ve müsabaka esnasında verimliliğinin artması, doğru zamanlama ile doğru tekniği sergileyebilmesi ise iyi antrene edilmiş bir sürat özelliğiyle gerçekleştirilebilir (Usgu, 2015).

Buradan yola çıkarak, basketbolda üst ve alt ekstremiteye ait anaerobik gücün sürat ile ilişkisinin olup olmadığı, ayrıca üst ve alt ekstremiteye ait anaerobik gücün laktat değerlerine etkisini araştırımasıdır. Çalışmadan elde edilen verilerin sonucunda, sporcuların teknik gelişimlerinin değerlendirilmesi ve takip edilmesi bununla birlikte uygun antrenman programlarının oluşturulmasına katkı sağlaması beklenmektedir.

\section{Yöntem}

\section{Araştırma Grubu}

Araştırmaya Türkiye Basketbol 2. Liginde yer alan 14 erkek basketbolcu gönüllü olarak katılmıştır. Katılımcıların ortalama boy uzunlukları $185.98 \pm 4.26 \mathrm{~cm}$, yaş ortalamaları 21.88 \pm 1.05 yıl ve vücut ağırlıkları ortalama $79.01 \pm 5.48 \mathrm{~kg}$ tespit edilmiştir. Çalışma öncesinde katılımcılara, yapılacak testler için bilgilendirme yapılmış ve performanslarını etkileyecek herhangi bir ilaç kullanmamaları sağlandı. Sporculardan, araştırmaya gönüllü olarak katılıklarına dair onam formu ve Karamanoğlu Mehmetbey Üniversitesi bilimsel araştırma ve etik kurulu tarafından (E95728670-044) numaralı onayı alındı.

\section{Veri Toplama Araçları}

Bacak Kuvveti Ölçümü. Baseline marka bacak dinamometresi kullanılarak yapılmıştır. Beş dakika ısınmadan sonra, katıımcılar dizleri bükük durumda dinamometre sehpasının üzerine ayaklarını yerleştirdikten sonra, kollar gergin, sırt düz ve gövde hafifçe öne eğikken, elleri ile kavradığı dinamometre barını dikey olarak maksimum oranda bacaklarını kullanarak yukarı çekmesi istenmiştir. Bu çekiş üç kez tekrar edilip her katıımcı için en iyi değer kaydedilmiştir (Han, 2018).

Sırt Kuvveti Ölçümü. Baseline marka sırt dinamometresi kullanılarak ölçümler yapılmıştır. Katıımcıların dizleri gergin pozisyonda dinamometre sehpasının üzerinde ayaklarını yerleştirdikten sonra, kollar gergin, sırt düz ve gövde hafif öne doğru eğikken, elleri ile kavradığı dinamometre barını dikey olarak maksimum oranda yukarıya çekmişlerdir. Çekiş üç kez tekrar edilmiş ve en iyi sonuç kaydedilmiştir (Han, 2018).

20 m Sürat Testi. Katılımcıların 20 m belirlenmiş alanda yüksek çıkış ile maksimal hıza çıkarak koşuyu tamamlamaları istenmiştir. Koşulan süre "sn" cinsinden Microgate Witty Double marka fotosel ile ölçülüp, test iki defa tekrar edilerek en iyi sonuç kaydedilmiştir (Ayan \& Mülazımoğlu, 2009).

Wingate Kol Anaerobik Güç Testi. WAnT testi için düzenlenmiş yazılımlı ve bilgisayarla uyumlu çalışan ağırlık kefeli bir Monark 891E model (Made in Sweden) kol bisiklet ergometresi kullanılmıştır. Test başlamadan her katılımcıya göre boy ayarlaması yapılmıştır. Test esnasında kol ergometresinde dış direnç olarak uygulanacak olan yük, $50 \mathrm{gr} / \mathrm{kg}$ olarak hesaplanmıştır. Belirlenen bu dirence karşı $30 \mathrm{sn}$ süresince en yüksek hızda pedal çevirmeleri istenmiş ve üst düzey performans göstermeleri için sözel 
olarak desteklenmişlerdir. Teste başlamadan önce oluşacak sakatlıkları önlemek için uygun spor kıyafetleri ile ısınmaları sağlanmıştır (Soslu vd., 2017).

Wingate Bacak Anaerobik Güç Testi. WAnT testi için düzenlenmiş yazılımlı ve bilgisayarla uyumlu çalışan ağırlık kefeli bir Monark 894E model bacak bisiklet ergometresi kullanılmıştır. Test başlamadan her katıımcıya göre boy ayarlaması yapılmıştır. Test sırasında bacak ergometresinde dış direnç yükü 75 $\mathrm{gr} / \mathrm{kg}$ olarak hesaplanmıştır. Hesaplanan test yüklerinin \%20'si ile 60-70 d/d hızda, 4-8 saniye süreli iki hız içeren, 5 dakikalık bir ısınma protokolü uygulanmıştır. Isınma bittikten sonra katılımcıların 3-5 dakika pasif dinlenmeleri sağlanmıştır. Direnç verilmeden yapabildikleri en kısa sürede en yüksek pedal hızına ulaşmaları istenerek, maksimum hıza ulaşıldığından emin olduğunda (yaklaşık 3-4 saniye sonra), bireysel olarak belirlenen yük bırakılarak test başlatılmıştır. Yüke karşı 30 saniye boyunca maksimum hızla pedal çevirmeleri istenmiş zaman süresince sözlü olarak teşvik edilmeleri sağlanmıştır (Soslu vd., 2019).

Kavrama Kuvveti. Kavrama kuvveti parametrelerini ölçmek için 0-100 kg. arası kuvvet ölçen (Takeı Grıp)el dinamometresi kullanılmıştır. El dinamometresi katıımcıların el ölçülerine göre ayarlanmış, dirseğini bükmeden kolu düz ve omuzdan 10-15 derecelik bir açı yapacak şekilde yan tarafta iken eli ile mümkün olan en yüksek eforla dinamometreyi sıkmaya çalışmıştır. Her iki eliyle iki denemeden sonra en iyi değer alınmıştır. Dinamometre her denemeden sonra sıfırlanmıştır (Soslu vd., 2019).

Kan Laktat Ölçümü. Sporcuların kan laktat değerleri WAnT testinden önce ve testten 1 dk sonra LactateScout (LS) Analyzer cihazı (Made in Germany) kullanılarak parmaklarından alınan kan değerleri mmol-1 cinsinden kaydedilmiştir (Soslu vd., 2018).

\section{Veri Analizi}

Verilerin analizinde sporculara ait sürat parametreleri ve alt ve üst anaerobik güç değerlerinin analizinde tanımlayıcı istatistik analizi (ortalama ve standart sapma), ölçümle elde edilen bağımsız değişkenlerin bağımlı değişkenler üzerindeki etkisini belirlemek için Lineer Regresyon Analizi SPSS (24.0) programı aracılığıyla incelenmiştir. Laktat testleri için ön ve son test değerleri Levene testi ile homojen dağılımı test edilmiş ve One Way Anova testi ile değerlendirilmiştir. Araştırma verilerinin değerlendirilmesinde anlamlılık olarak $p<0.05$ değeri alınmıştır.

\section{Bulgular}

Bu araştırmada katıımcılardan elde edilen üst ekstremite zirve güç, üst ekstremite ortalama güç, üst ekstremite en yüksek güçte zaman, alt ekstremite zirve güç, alt ekstremite ortalama güç, alt ekstremite en yüksek güçte zaman, laktat ve $20 \mathrm{~m}$ sprint değerleri belirlendi. Verilerin analizinde katılımcılara ait sürat parametreleri ve alt ve üst anaerobik güç değerlerinin analizinde tanımlayıcı istatistik analizi (ortalama ve standart sapma), ölçümle elde edilen bağımsız değişkenlerin bağımlı değişkenler üzerindeki etkisini belirlemek için Lineer Regresyon Analizi ile incelendi. Laktat testleri için ön ve son test değerleri One Way Anova testi ile değerlendirildi.

Tablo 1. Katılımcıların boy uzunlukları, yaş ve vücut ağırlıkları ortalama değerleri.

\begin{tabular}{lccc}
\hline Değişkenler & $\mathbf{n}$ & $\mathbf{X}^{-}$ & SS \\
\hline Yaş & 14 & 21.88 & 1.05 \\
Boy & 14 & 185.98 & 4.26 \\
Vücut Ağırlığı & 14 & 79.01 & 5.48 \\
\hline
\end{tabular}


Tablo 1 incelendiğinde, katılımcıların ortalama boy uzunlukları $185.98 \pm 4.26 \mathrm{~cm}$, yaş ortalamaları $21.88 \pm 1.05$ yıl ve vücut ağırlıkları ortalama $79.01 \pm 5.48$ kg olarak tespit edilmiştir.

Tablo 2. Katılımcıların Wingate kol ve bacak testi değerleri.

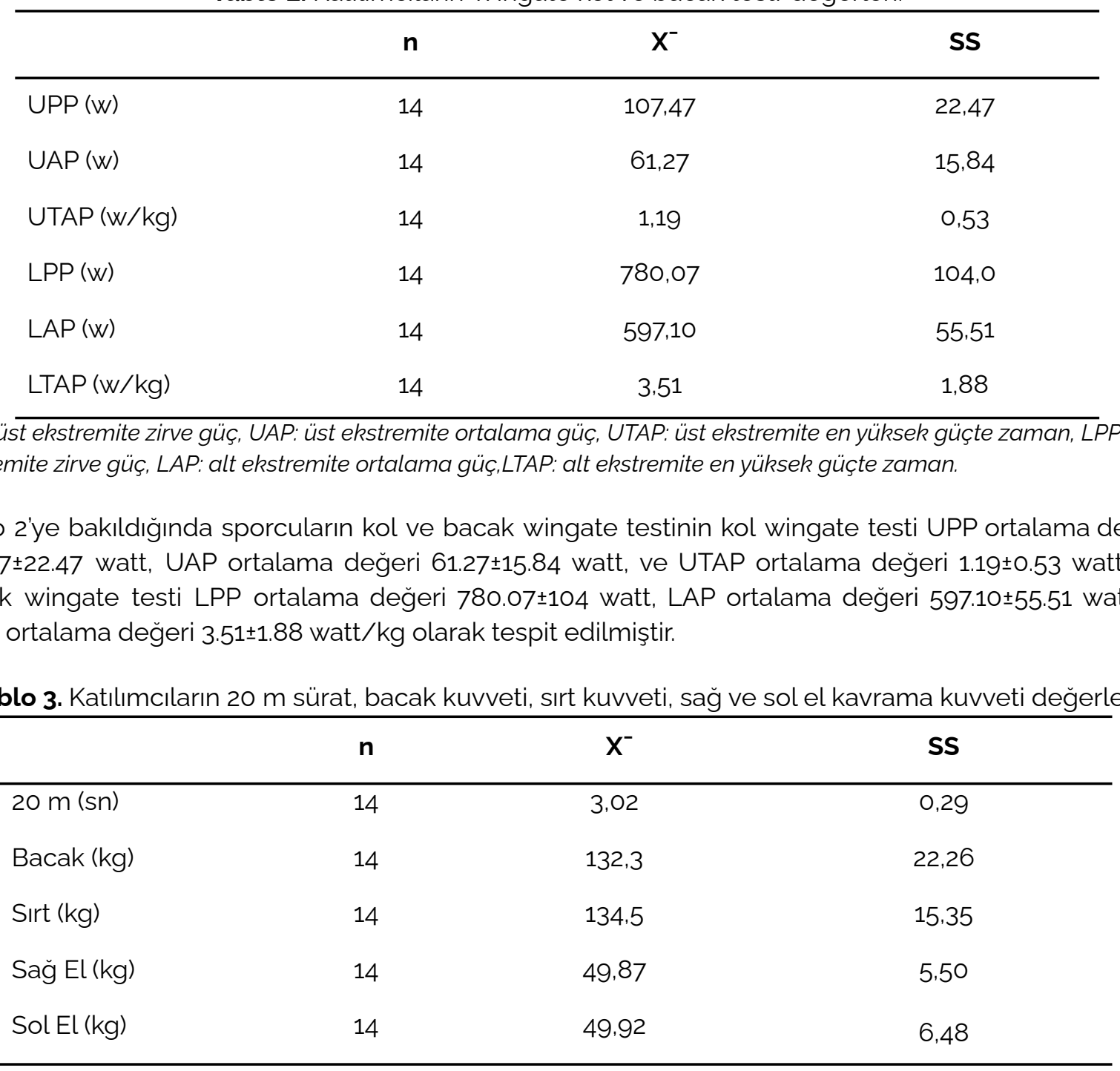

Tablo 3'e bakıldığında sporcuların $20 \mathrm{~m}$ koşu ortalama değeri 3.02 \pm 0.29 sn bacak ortalama değerleri $132.39 \pm 22.26 \mathrm{~kg}$ sırt kuvveti ortalama değeri $134.57 \pm 15.35 \mathrm{~kg}$, sağ el kavrama kuvveti ortalama değeri $49.87 \pm 5.50 \mathrm{~kg}$, sol el kavrama kuvveti ortalama değeri $49.92 \pm 6.48 \mathrm{~kg}$ olarak tespit edilmiştir.

Tablo 4. Katılımcılara ait Wingate kol ve bacak testi öncesi ve sonrası laktat değerleri.

\begin{tabular}{lcccc}
\hline & $\mathbf{n}$ & $\mathbf{X}^{-}$ & $\mathbf{S S}$ & $\mathbf{p}$ \\
\hline $\operatorname{ULKTB}(\mathrm{m} / \mathrm{mol})$ & 14 & 2,08 & 0,89 & $\mathbf{0 , 0 2}$ \\
$\operatorname{ULKTA}(\mathrm{m} / \mathrm{mol})$ & 14 & $6,35^{*}$ & 2,31 & \\
$\operatorname{LLKTB}(\mathrm{m} / \mathrm{mol})$ & 14 & 2,56 & 0,69 & $\mathbf{0 , 0 0 1}$ \\
$\operatorname{LLKTA}(\mathrm{m} / \mathrm{mol})$ & 14 & $8,14^{*}$ & 1,59 & \\
\hline O O5 ULKTB: üst ekstremite laktat önce, ULKTA: üst ekstremite laktat sonra, LLKTB: alt ekstremite laktat önce, \\
KTA: alt ekstremite laktat sonra.
\end{tabular}


Tablo 4'e bakıldığında sporcuların antrenman öncesi ve sonrası kol laktat değerleri ULKTB ve ULKTA ortalama değerleri sırasıyla $2.08 \pm 0.89 \mathrm{mmol}, 6.35 \pm 2.31 \mathrm{mmol}$, bacak LLKTB ve LLKTA ortalama değerleri sırasıyla $2.56 \pm 0.69 \mathrm{mmol} 8.14 \pm 1.59 \mathrm{mmol}$ olarak tespit edilmiştir. Ayrıca ULKTB ve ULKTA,LLKTB ve LLKTA bağımlı değişkenlerine göreön ve son test değerleri arasında son testlerinde laktat artışında anlamlı fark tespit edilmiştir ( $p<0,02$ ve $p<0,001)$.

Tablo 5. Katılımcıların 20 m sürat ile Wingate kol ve bacak testi değerleri arasındaki regresyon analizi.

\begin{tabular}{|c|c|c|c|c|}
\hline Model & df & $X^{-2}$ & $\mathbf{F}$ & $p$ \\
\hline Regression & 6 & 0,60 & 0,559 & 0,752 \\
\hline Fark & 7 & 0,107 & & \\
\hline Toplam & 13 & & & \\
\hline
\end{tabular}

Tablo 5'e bakıldığında sporcuların 20 m sürat ile bağımlı değişkenler UPP, UAP, UTAP, LPP, LAP, LTAP değerleri arasında Regresyon analizi sonucuna göre istatistiksel olarak anlamlı fark tespit edilmemiştir $\left(F_{(6,13)}=, 55 ; p>0,05 ; R^{2}=-, 25\right)$.

Tablo 6. Katılımcıların 20 m sürat ile bacak, sırt ve el kavrama kuvveti değerleri arasında regresyon analizi.

\begin{tabular}{|c|c|c|c|c|}
\hline Model & df & $X^{-2}$ & $\mathbf{F}$ & $p$ \\
\hline Regression & 4 & 0,026 & 0,229 & 0,915 \\
\hline Fark & 9 & 0,112 & & \\
\hline Toplam & 13 & & & \\
\hline
\end{tabular}

Tablo 6'e bakıldığında sporcuların 20 m sürat ile bağımlı değişkenler bacak, sırt ve el kavrama kuvvet değerleri arasında Regresyon analizi sonucuna göre istatistiksel olarak anlamlı fark tespit edilmemiştir $\left(F_{(6,13)}=, 22, p>0,05, R^{2}=-, 31\right)$.

\section{Tartışma}

Bu çalışmada, basketbolda üst ve alt ekstremiteye ait anaerobik gücün sürat ile ilişkisinin olup olmadığı, ayrıca üst ve alt ekstremiteye ait anaerobik gücün laktat değerlerine etkisini araştırımasıdır. Maksimal ve supramaksimal fiziksel aktivite sırasında iskelet kaslarının anaerobik enerji transfer sistemlerini kullanarak meydana getirir. Anaerobik iş, patlayıcı gücün ortaya konması anlamına gelen, anaerobik eşik değer üzerinde bir iş yükü olup, yorgunluk ile kendini gösteren fiziksel aktivite tipidir. Anaerobik aktiviteye uzun süre devam edilemez. Zira iskelet kasları steady-rate oksijen metabolizmasının çok üzerinde, anaerobik metabolizma ile çalışmaktadır. Bu durumda kas ve kan laktat seviyesi yükselir. Biriken laktatın tamponlanması akciğerlerden $\mathrm{CO} 2$ atıımını artıır ve $\mathrm{pH}$ düşmesi $(\mathrm{pH}=6,4)$ nedeniyle kaslarda yorgunluk meydana gelir.

Basketbolda kısa süreli şiddeti yüksek aksiyonlar için gerekli performansı yükseltmek amacıyla anaerobik güç değerlendirmesi yapmak çok önemlidir. Basketbolda anaerobik güç ve kapasite değerlendirilmesi özellikle uzun mesafe pas ya da uzun mesafeli şutlarda, topu çembere gönderebilmek için hızlı yer değiştirmelerde, topa uzanabilmek için ani sıçramalarda, ribaunt almada, savunmada alınan topla hızı bir şekilde hücum gerçekleştirebilmek için son derece önemlidir (Akgün, 
1994: Conconi vd., 1982). Buna benzer çalışmalarda, anaerobik performans ile sprint hızı arasında güçlü ve negatif korelasyon (0,67 ile 0,91 aralığında) olduğunu belirtmişlerdir (Kaczkowski vd., 1982; Patton vd., 1987). Ayrıca anaerobik güç ve kapasite testi sonucunda elde edilen Maksimum Güç (MG) ve Relatif Maksimum Güç (RMG) değerleri arasında negatif yönde anlamlı bir ilişki olduğunu belirtmişlerdir (Sağıroğlu, 2008; Yılmaz, 2011). Çalışmamızda, sporcuların, kol ve bacak anaerobik güç değerleri değerlendirilmiştir. Basketbolda etkin olarak kullanılan kol ve bacaklar üretilen güç ile performans arasında yakın ilişkide olduğunu belirtmektedir.

Basketbolcuların dominant ve non-dominant taraf kavrama kuvvetlerinin turnike, şut, ribaunt ve top sürme becerileri üzerine etkisi olduğu bilinmektedir(Akyüz vd., 2017). Dar oyun alanı ile birlikte, basketbolun yüksek şiddetli aralıklı doğası, oyuncuların sürekli olarak ani değişikliklere hızı ivmelenme ve yavaşlama yapmalarını gerektirir. Çok hızlı değişen geçişler arasında pozisyonu koruyabilmek için sürat ve kas kuvveti önemli etkenlerdir (McArdle vd., 2010). Basketbolun \%80 anaerobik enerji sistemini kullanmasıyla aerobik sistemde meydana gelen adaptasyonlardan kaynaklı olduğunu ve bu adaptasyonlardan bazılarının, hızlı kasılan lif sayısında artış, ATP-PCr ve anaerobik glikoliz kapasitesindeki artışın neden olduğunu ifade etmişlerdir(Soslu vd., 2019). Basketbolcularda hız, çeviklik ve patlayıcı güç için gerekli fiziksel parametreleri değerlendirildiğinde yapılan birçok çalışma kullanılan enerji sistemleri ile kasılmaya katılan kas lifi sayısının önemli derecede etki ettiğini belirtmektedir(Aslan vd.,2011; Ayan \& Erol, 2015; Bakırcı \& Kılınç, 2014; Bilgin, 2015; Yazarer vd., 2004). Tüm spor dallarında olduğu gibi basketbolda da temel motorik özelliklerin geliştirilmesi uygulanan antrenmanların vazgeçilmez bir bölümünü oluşturur. Sportif başarının temelinde, temel motorik özelliklerin geliştirilmesi ön şartlardan birisidir ve bunun içinde en önemli bölümünü de kuvvet oluşturur. Basketbolda da kuvvet temel unsurlardan bir tanesidir. Sıçrama kuvveti, atış kuvveti ve sprint yeteneği önem arz etmekte ve bu özelliklerin oluşması için uyluk, gövde, göguüs, sırt ve kol kasları önemli etkenlerdendir. 30-60 saniye sürede maksimum mekik ölçümleriyle beraber göreceli güç, squat, bench press, vertikal sıçrama, 40-20 m sürat testi gibi sportif performans ölçümleri içinde olumlu bir ilişki olduğu gözlemlenmektedir (Dendas, 2010). Yine literatür incelendiğinde bir çok çalışma basketbolculara ait kuvvet, sürat gibi önemli motorik özelliklerin geliştirilmesinde farklı antrenman programları uygulamışlardır (Akyüz vd.,2013;Akyüz vd., 2017; Çimen, 2013; Hekim, 2012). Ayrıca kuvvet performans ilişkisi de bu yönüyle incelemiş, pozitif yönlü bir ilişki olduğunu belirtmişlerdir. Çalışmamız sporcuların sürat ve kuvvet değerlerinin antrenman içerikleri ve bireysel farklılık gösterse de literatür ile yapısal olarak benzer olduğunu ve basketbolda önemli bir yer tuttuğunu ifade edebiliriz.

Basketbol aksiyonlarında yüksek enerjili fosfatlar içeren enerji sistemine dayanır. Hızlı çıkışlar, yön değiştirmeler ve paslar gibi birçok aksiyon için enerji gereksinimi yüksek enerjili fosfatlardan sağlanır. Bu bakımdan kas içi yüksek enerjili fosfat düzeyi maksimal veya supramaksimal yoğunlukta, kısa süreli aktivitelerde performansı önemli derecede etkiler. Maksimal performansı da fosfat düzeyinin belirlediği düşünülmektedir. Egzersiz yoğunluğu tedricen yükseldiğinde, oksijen yetersizliğinin başladığı noktada, ATP re-sentezi anaerobik metabolizma ile desteklenir. Kas ve kanda laktik asit birikmeye başlar. Egzersiz süresi ilerleyince, kasların iş yükü artar ve VCO2, oksijen kullanımına cevap olarak değil de, kan laktat tamponlanması sonucu yükselmeye başlar. Bunun sonucunda performans olumsuz etkilenir. Basketbolda kısa süreli bu değişimler değerlendirildiğinde kan laktat düzeyleri önemli bir yer tutmaktadır. Çalışmamızda sporcuların antrenman öncesi ve sonrası kol laktat değerleri ULKTB ve ULKTA ortalama değerleri sırasıyla $2.08 \pm 0.89 \mathrm{mmol}, 6.35 \pm 2.31 \mathrm{mmol}$, bacak LLKTB ve LLKTA ortalama değerleri sırasıyla 2.56 $\pm 0.69 \mathrm{mmol}, 8.14 \pm 1.59 \mathrm{mmol}$ olarak tespit edilmiştir. Laktat konsantrasyonunu belirlemek için benzer çalışmalar incelendiğinde egzersiz öncesi ve sona kan laktat düzeylerinde artışın olduğu belirtilmektedir (Abdelkrim vd., 2007; Soslu vd., 2018; Şişman 2016;Turan 2001) ve bu yönüyle çalışmamızla paralellik göstermektedir. 


\section{Sonuç}

Basketbolcuların fiziksel, fizyolojik özelliklerinin bilinmesi bu spora bilimsel yaklaşım ve katkıları arttıracak ve performans değerlendirilmesinde kuvvet, sürat ve anaerobik güç gibi parametreler oldukça önemli bir yer tutacaktır. Sonuç olarak basketbolcuların anaerobik gücünün müsabaka anında önemli bir etken olacağı bunun da sporcuların performanslarını pozitif yönde etkileyeceği düşünülebilir. Basketbolcularda sürat ile kuvvet ve sürat ile anaerobik güç arasında ilişkiler göz önüne alınarak sporcuların performanslarını olumlu düzeyde etkileyecek antrenman programları yazılabilir.

\section{Kaynakça}

Abdelkrim, N.B., El Fazaa,S.,\&Elati ,J. (2007). Time motion analysis and physiological data of elite under 19 year old basketball players during competition. British Journal of Sports Medicine, 41(2) 69-75.

Akgün, N. (1994). Egzersiz ve spor fizyolojisi. 5. Baskı, Izmir: Ege Üniversitesi.

Akyüz, M., Özkan, A., Taş, M., Sevim, O., Akyüz, Ö., \& Uslu,S. (2013). Yıldız basketbol milli takımında yer alan kız sporcuların kuvvet profillerinin belirlenmesi ve ilişkilendirilmesi. International Journal of Sport Culture and Science, 1(3), 39-48.

Akyüz, M., Özmaden, M., Doğru, Y., Karademir, E., Aydın, Y., \& Hayta, Ü. (2017). Genç basketbolcularda statik ve dinamik germe egzersizlerinin bazı fiziksel parametrelere etkisi. Journal of Human Sciences, 14(2), 1492-1500.

Aslan, C.S., Büyükdere, C., Köklü, Y., Özkan, A., \& Özdemir, F.N.Ş. (2011). Elit altı sporcularda vücut kompozisyonu, anaerobik performans ve sırt kuvveti arasındaki ilişkinin belirlenmesi. Uluslararası insan Bilimleri Dergisi, 8(1), 1612-28.

Atlı, A. (2009). 14-16 yaşları arasındaki erkek basketbolcu, futbolcu ve sedanterlerin bazı fiziksel, fizyolojik ve antropometrik özelliklerinin karşılaştırılması. (Yayımlanmamış yüksek lisans tezi). Selçuk Üniversitesi, Sağlık Bilimleri Enstitüsü, Konya.

Ayan, M., \& Mülazımoğlu, O. (2009). Sporda yetenek seçimi ve spora yönlendirmede 8-10 yaş grubu erkek çocuklarının fiziksel özelliklerinin ve bazı performans profillerinin incelenmesi. Fırat Üniversitesi Sağlık Bilimleri Tıp Dergisi, 23(3), 113-118.

Ayan, V.,\& Erol, E. (2015). Türk yıldız milli erkek basketbol takım sporcularının somatotip yapılarının ve performans özelliklerinin incelenmesi. Kastamonu Eğitim Dergisi, 24(4), 2096.

Bakırcı, A.,\& Kılınç, F. (2014). Hazırlık periyodunda uygulanan kombine antrenmanların üniversite basketbol takımının performans düzeyine etkisi. Inönü Üniversitesi, Beden Eğitimi ve Spor Bilimleri Dergisi, 1(2), 61-64.

Bilgin, M. (2015). Dinamik stretching uygulamalarının 18-23 yaş arası erkek basketbol oyuncularının sürat performansına etkisinin incelenmesi. (Yayımlanmamış yüksek lisans tezi). Kocaeli Üniversitesi, Sağlık Bilimleri Enstitüsü. Kocaeli.

Bompa, T.O. (2011).Antrenman kuramı ve yöntemi (4.Baskı). Ankara: Bağırgan Yayınevi. 
Castagna, C., Abt, G., Manzi, V., Annino, G., Padua, E., \& D'Ottavio, S. (2008). Effect of recovery mode on repeated sprint ability in young basketball players. The Journal of Strength \& Conditioning Research, 22(3), 923-929.

Conconi, F., Ferrari, M., Ziglio, P. G., Droghetti, P., \& Codeca, L. (1982). Determination of the anaerobic threshold by a noninvasive field test in runners. Journal of Applied Physiology, 52(4), 869-873.

Çimen, E. (2013).12-14 yaş arası müsabaka döneminde hentbolcularda kombine uygulanan aerobik ve anaerobik antrenmanların kondisyonel ve teknik performansları üzerine etkilerinin araştırılması. (Yayımlanmamış yüksek lisans tezi). Süleyman Demirel Üniversitesi, Sağlık Bilimleri Enstitüsü, Spor Bilimleri Anabilim Dalı, Isparta.

Dendas, A. M. (2010). The relationship between core stability and athletic performance. California: (Unpublished doctoral dissertation). Humboldt State University,

Güngör, H. (2019). Profesyonel basketbol oyuncularının solunum fonksiyonları ve fiziksel uygunluk parametrelerinin sedanter kontrollerle karşılaştırılması. (Yayımlanmamış yüksek lisans tezi). Hacettepe Üniversitesi, Sağlık Bilimleri Enstitüsü, Kardiopulmoner Rehabilitasyon Programı, Ankara.

Han, M. (2018). 1. lig ampute futbol takımlarında bacak ve el kavrama kuvvetinin sportif performansa etkisi. (Yayımlanmamış yüksek lisans tezi). İnönü Üniversitesi Sağlık Bilimleri Enstitüsü.

Hamzaoğulları, A. (2009). Çabuk kuvvet ve aerobik çalışmaların amatör futbolcuların kan lipidleri üzerine etkileri. (Yayımlanmamış yüksek lisans tezi). Fırat Üniversitesi Sağlık Bilimleri Enstitüsü, Beden Eğitimi Spor Anabilim Dalı, Elazığ.

Hekim, M. (2012).Atletizm ve basketbol sporuna katılan 10-13 yaş grubu kız çocukların kuvvet ve anaerobik güç değerlerinin sürat performansı ve kan laktat seviyesine etkisi. (Yayımlanmamış yüksek lisans tezi). Sakarya Üniversitesi, Eğitim Bilimleri Enstitüsü, Beden Eğitimi ve Spor Öğretmenliği Ana Bilim Dalı, Sakarya.

Kaczkowski, W., D.L. Montgomery, A.W. Taylor,\& V. Klıssouras. (1982). The Relationship between muscle fibre composition and maximal anaerobic power capacity. Journal of Sports Medicine. 22:407-413.

Kostromin, S. (2015). Basketbolcularda anaerobik kapasitenin saha ve laboratuvar ortamında karşılaştırılması. (Yayımlanmamış yüksek lisans tezi). Oxford Spor Bilimleri Fakültesi, Amerika Birleşik Devletleri.

McArdle, W. D., Katch, F. I., \&Katch, V.L. (2010). Exercise Physiology: nutrition, energy, and human performance. Lippincott Williams \& Wilkins.

Menevşe, A. (2013). Basketbolcuların oynadıkları pozisyonlara göre anaerobik güçlerinin karşılaştırılması. Spor ve Performans Araştırmaları Dergisi, 4(1), 33-37.

Montgomery, P.G., Pyne, D.B., \& Minahan, C.L. (2010). The physical and physiological demands of basketball training and competition. International Journal of Sports Physiology and Performance, 5(1), 75-86.

Özdenk, S. (2019). Çocuklarda kuvvet antrenmanı. Spor ve Rekreasyon Araştırmaları Dergisi, 124-138. 
Patton, J. F.,\& Duggan, A. (1987). An evaluation of tests of anaerobic power. Aviation, Space, and Environmental Medicine. 58:237-242

Sağıroğlu, i. (2008). Genç basketbolcularda pliyometrik antrenmanların anaerobik performans ve dikey sıçrama yüksekliğine etkisi. (Yayımlanmamış yüksek lisans tezi). Dokuz Eylül Üniversitesi, Sağlık Bilimleri Enstitüsü, Spor Fizyolojisi Bilim Dalı, İzmir.

Sevim, Y. (2002). Basketbol teknik-taktik-antrenman. 5.Baskı Ankara: Nobel Yayın Dağıtım,

Soslu, R., Eyüboğlu, E., Çuvalcığlu, i. C., \& Özkan, A. (2017). Kadın basketbolcularda bazı kan parametrelerinin ve morfolojik değişkenlerin üst ekstremiteden elde edilen bazı performans değerlerine etkisi. Uluslararası Kültürel ve Sosyal Araştırmalar Dergisi (Uksad), 3 (Special Issue 2), 347-353.

Soslu, R., Güler, M., Ömer, Ö., Devrilmez, M., Cincioğlu, G., Doğan, A.A., \& Esen, H.T. (2018). Boksörlerde akut yorgunluğun statik dengeye etkisi. Sportive, 1(1), 19-30.

Soslu, R., Özer, Ö., Güler, M., \& Doğan, A. A. (2019). Is there an effect of core exercises on anaerobic capacity in female basketball players? Journal of Education and Training Studies, 7(3), 99-105.

Şişman, A. (2016).Menstrual döngü fazlarında yüksek yoğunluklu kısa süreli yüklenmenin postural kontrole etkisi. (Yayımlanmamış yüksek lisans tezi). Selçuk Üniversitesi, Sağlık Bilimleri Enstitüsü, Antrenörlük Eğitimi Anabilim Dalı, Konya.

Turan, I. (2001).Elit ve elit olmayan genç basketbol oyuncularında fizyolojik profillerinin karşılaştırılması. (Yayımlanmamış yüksek lisans tezi). Trakya Üniversitesi, Sağlık Bilimleri Enstitüsü, Beden Eğitimi ve Spor Ana Bilim Dalı, Edirne.

Usgu, S. (2015). Profesyonel basketbol oyuncularında fonksiyonel eğitimin performansla ilişkili fiziksel uygunluk parametrelerine etkisi. (Yayımlanmamış doktora tezi), Hacettepe Üniversitesi, Sağlık Bilimler Enstitüsü, Ankara.

Yazarer, i., Taşmektepligil, M. Y., Ağaoğlu, Y. S., \& Ağaoğlu, S. A. (2004). Yaz spor okullarında basketbol çalışmalarına katılan grupların iki aylık gelişmelerinin fiziksel yönden değerlendirilmesi. Spormetre Beden Eğitimi ve Spor Bilimleri Dergisi, 2(4), 163-170.

Ziv, G.,\& Lidor, R. (2009). Physical attributes, physiological characteristics, on-court performance nutritional strategies of female and male basketball players. Sports Medicine, 39(7), 547-568. 